\title{
The Impact of Icts on Hospitality Sector of Tourism in Zambia
}

\author{
Francis Chama Mulubwa \\ Ministry of Tourism \& Arts, Department of National Parks and Wildlife, Livingstone, Zambia
}

\author{
Syed Ali*
}

Professor of Economics, Mulungushi University, Kabwe, Zambia

\begin{abstract}
This study aimed to investigate the impact of mobile phone, land phone and internet (ICTs) on sales, market performance, room occupancy, profitability and credit facilities in the hospitality sector of tourism in the tourist city of Livingstone in Zambia. The study used multiple regression models to find out the relationship between dependent and independent variables. The study found that there was positive impact of ICTs usage on sales, marketing performance, room occupancy, profitability and credit facilities. The study found negative relationship between internet and profitability of the firm due to higher costs of internet access. The study suggested that the firms should work together as a pool to reduce internet costs, such as, the use of trivago.co.zm; booking.co.zm; hotels.com; agoda.com; expedia.com; etc.
\end{abstract}

Keywords: ICTs; Sales; Market performance; Profitability; Credit facilities; Internet cost.

(ㄷ) (1) CC BY: Creative Commons Attribution License 4.0

\section{Introduction}

Tourism occupies 10 percent of world's GDP; one out of ten persons are employed in tourism industry; 7 percent of world's exports, 30 percent of services exports and the value of exports is US\$ 1.6 trillion; international tourist arrivals increased by 7 percent, reaching 1,323 million and the total international tourism receipts increased by 5 percent, reaching US\$ 1,340 billion (UNWTO, 2018). Tourism is a main source in fostering multicultural understanding and it contributes to the preservation of cultural and natural heritage. The Sustainable Development Goals identified tourism as a source of creating jobs and promoting local culture and products (UNWTO, 2015). The tourism is one of the leading job creators in the world. The share of world employment in travel and tourism is greater than that for the auto manufacturing and chemicals manufacturing industries combined, across every region of the world (World Economic Forum, 2013). One job in tourism generates 1.5 jobs elsewhere (UNWTO, 2014). Tourism is one of the priority sectors for development in Zambia and has the potential to be a major contributor to social and economic development of the country (Ali, 2015).

\subsection{Statement of the Problem}

But there are challenges in using information and communication technologies (ICTs) in hospitality sector of tourism in Zambia. The understanding about the importance of ICTs and investment in them is less. As a result, the hospitality sector of tourism in Zambia has been facing challenges in competitive advantage, sales, profitability and access to finance. Hence, this study investigates the status of use of ICTs and its impact on sales, profitability and access to finance of hospitality sector of tourism.

\subsection{Objectives}

The general objective of this paper is to find out the status of use of ICTs and its impact on profit and access to credit in the hospitality sector of tourism. The specific objectives are to:

1. Know the use of different types of ICTs in the hospitality sector

2. Ascertain the relationship between ICTs usage and sales \& marketing performance of the firm.

3. Find out the impact of ICTs on room occupancy rate

4. Investigate the relationship between ICT usage and profitability of the firm.

5. Examine the effect of ICTs usage on access to credit.

\subsection{Hypotheses}

Null Hypothesis: There is no impact of use of ICTs on room occupancy, profitability and access to credit.

Alternative Hypothesis: There is positive impact of usage of ICTs on room occupancy, profitability and access to credit. 


\subsection{Review of Literature}

\subsubsection{Theoretical Literature Review}

a. Porter's Five Forces Analysis (Porter, 1998)

Porter's five forces analysis includes threat of new entrants, bargaining power of suppliers and customers, threat of substitute products of service and bargaining power of competitors. The internet as a distribution source has relatively high entry barriers, constraining all new comers.

A more successful strategy would be to enter into joint ventures or expand a supplier's website to offer competitors' products. The provision of online travel services is the single most successful business-to-consumer segment on the internet. Travel agencies are the main substitute to the internet sales with respect to buying hotel bedrooms or tourism packages. The competitive environment of internet and its impact on the tourism and hospitality industries is widely recognized as being complex, dynamic, and highly segmented.

\section{b. Information and Communication Technologies (ICTs) in the Tourism sector}

The internet has become a key application in the tourism industry. The tourism industry at first focused on utilizing computerized systems to increase efficiency in processing of internal information and managing distribution. Nowadays, the Internet and ICTs are relevant on all operative, structural, strategic and marketing levels to facilitate global interaction among suppliers, intermediaries and consumers around the world (Mupfiga, 2015).

\section{c. Electronic Tourism (e-Tourism)}

Electronic tourism is the application of ICTs on the tourism industry. E-tourism reflects the digitization of all processes and value chains in the tourism, travel, hospitality and catering industries. The e-tourism concept includes all business functions (i.e., e-commerce, e-marketing, e-finance and e-accounting, e-HRM, e-procurement, eproduction) as well as e-strategy, e-planning and e-management for all sectors of the tourism industry, including tourism, travel, transport, leisure, hospitality, principals, intermediaries and public sector organizations. Hence, etourism bundles together three distinctive disciplines: business management, information systems and management, and tourism (Buhalis, 2003).

\section{d. Computer Reservation System (CRS)}

It is a database which enables a tourism organization to manage its inventory and make it accessible to its partners. Principals utilize CRSs to manage their inventory and distribute their capacity as well as to manage the drastic expansion of global tourism. CRSs often charge competitive commission rates while enabling flexible pricing and capacity alterations, to adjust supply to demand fluctuations. Airlines pioneered this technology, although hotel chains and tour operators followed by developing centralized reservation systems. CRSs can be characterized as the "circulation system" of the tourism product.

\section{e. E-Travel Agencies}

ICTs are irreplaceable tools for travel agencies as they provide information and reservation facilities and support the intermediation between consumers and principals. Travel agencies operate various reservation systems, which mainly enable them to check availability and make reservations for tourism products. Until recently Global Distribution Systems (GDSs) have been critical for business travel agencies to access information and make reservations on scheduled airlines, hotel chains, car rentals and a variety of ancillary services. GDSs help construct complicated itineraries, while they provide up-to-date schedules, prices and availability information, as well as an effective reservation method. In addition, they offered internal management modules integrating the "back office" (accounting, commission monitor, personnel) and "front office" (customers" history, itinerary construction, ticketing and communication with suppliers). Multiple travel agencies in particular experience more benefits by achieving better coordination and control between their remote branches and headquarters (Mupfiga, 2015).

\section{f. The Hospitality Sector}

The quality of the hotel and its services is usually indicated by a star-rating system with one to five being most common. Luxury hotels, which are normally classified with a four and five star rating (governed by the country classification standards), are termed as upscale (i.e. up market) hotels. In business, upscale and up market reflect the market designed for higher-income consumers. Therefore, upscale full service hotels offer luxury amenities, full service accommodations, and on-site full service restaurants, in addition to the highest level of personalized and professional service.

\section{g. Information and Communication Technology (ICT)}

Modern ICT has created a "global village" in which society and establishments can use a vast range of new communication capabilities to communicate across the world in real-time. For this reason, ICT is regularly examined in the context of how modern ICT affects societies and business.

\section{h. ICT Solutions for the Hospitality Sector}

The hospitality industry has been a dominant contributor in several economies in term of employment and revenue (Nwakanma et al., 2014). It is currently the fastest growing economic sector in the world (Chevers, 2015). 
A significant part of this success is attributed to the adoption of ICT (Nwakanma et al., 2014; Xiang and Richard, 2013). It is common to acknowledge that ICT has an impact in several societies and businesses (Seng, 2015). For hospitality industry, considerable investment in ICT solutions is spent in designing services/products and improving hotel operation annually (Paryani et al., 2010).

With the growing trends in using ICT in all areas of business, ICT is gaining importance in the current era (Nwakanma et al., 2014). Nowadays, ICT has become a main source of sustainable competitive advantage and a strategic weapon that organizations rely on in light of fierce competition in the market (Mihalič et al., 2015; Nwakanma et al., 2014). In fact, some academics consider that ICT can lead to economic development of nations (Aziz et al., 2012).

According to Ham et al. (2005), Hotel Information System (HIS) is the most typical ICT solution in hotel establishments. They divided HIS into four main categories as follows: (i) Front-Office ICT systems; (ii) BackOffice ICT systems; (iii) Room division ICT systems; and (iv) In-room ICT systems. These areas cover the full complement of services provided by hotels to their local and overseas guests.

\section{i. The Effect of ICT on Sustained Competitive Advantage}

Because of the increasing benefits from ICT, hospitality firms have gradually invested more in ICT to increase overall efficiency (Kim et al., 2008) and to develop effective marketing strategies (Piccoli, 2008).

ICT support companies reach out to customers quickly and without geographical limitations and can produce added value for these customers by allowing a quick launch in the market of new services and products including Web catalogues with prices and descriptions - for a better availability to end customers (Paço and Pérez, 2015). ICT can provide many advantages for hotels of all sizes (Aziz et al., 2012). One of these advantages is higher quality customer relationships as a result of the possibility of personal dialogue and contact services with the customer (Wang, 2008). The positive influence may also include networking to share resources and information within and across the hotels to improve check-in, billing, transactions, and check out (Ansah et al., 2012).

Hotels need time to recognize the competitiveness potential of every new resource, and once they start to implement its importance may change over time (Mihalič et al., 2015). The adoption of ICT systems can restructure the work environment and modify job design. The lack of training is one of the barriers to full exploitation of ICT (Murphy H. C., 2013). Therefore, perhaps, tourism is behind in ICT adoption than other industrial sectors (Reino et al., 2013).

\section{j. Factors Determining ICT and Marketing Performance in Hospitality Sector}

The firm's tendency to adopt ICT is an indicator of its tendency towards innovativeness, and also echoes its capability to assess, accept and implement new technologies (Nwakanma et al., 2014).

The level of ICT developments in the hospitality industry may differ across the characteristics of hotels and their customer segments (Karadag and Dumanoglu, 2009). The findings of the study (Ngatia et al., 2014) in Kenya's hotel industry indicate the fact that the five factors are significant for ICT adoption in different ways. The factors are: the organisation resources, hotel size; manager characteristics, employees characteristics, and competition.. Hotel size may have a significant effect on ICT adoption propensity. Hotel size can also influence the marketing performance Mc. Manus (2013).

\subsubsection{Empirical Literature Review}

According to Lee and Shafer (2003) ICT solutions implemented in hotel rooms have not only enhanced in-room services, but also offered new opportunities for entertainment. In a study of upscale in Thailand acknowledged the dominant impact of some ICT (Prayukvong et al., 2007) amenities (e.g. mini bar, television, telephone service) on customer satisfaction without regard to "socio-demographice characteristics of the guests. However, a study conducted by Ham et al. (2005) in Korean upscale hotels, revealed that some guest-related interface solutions (e.g. electronic locks, call accounting, energy management and information services) had no significant influence on hotels' performance.

Networking ICT improves cost effectiveness, quicker communications, and efficient management of data and effective exchange of information (Ansah et al., 2012). Literature on the Internet was mainly used by hotels as a means of communication, transaction and competitiveness (Schegg and Scaglione, 2013). For example, Litvin et al. (2008) found that there are increasing numbers of travelers sourcing the internet to obtain destination information and to conduct transactions online.

Internet Marketing, e-Mail marketing, Electronic Data Interchange (EDI) for marketing activities, Mobile Marketing, and Customer relationship management (CRM) are some of the e-Marketing tools. The omnipresent nature of the internet has revolutionized hospitality marketing (Murphy J. et al., 2016). Hotels can exploit potential markets by having a website to promote and market their facilities and outstanding features". Law et al. (2009) contends that the internet may reduce the human interface between customers and suppliers.

According to Ali and Christopher (2017) hospitality industry is facing many challenges, including volatility in exchange rates. Hence there is need to find out the impact of exchange rate volatility on profitability and capacity utilization in hospitality industry in Zambia. Unstable exchange rates may affect business differently. The study revealed that, whenever the exchange rate improved by one Kwacha, profitability increased by 33 Kwacha per available room. There was insignificant negative relationship between inflation and profitability. The negative relationship was due to increase in hotel' operational costs as a result of the rise in inflation. One percentage point 
increase in inflation rate led to the decrease of $2 \mathrm{Kwacha}$ profit per room. Appreciation of the Zambian Kwacha against United States Dollar increased profitability and capacity utilization.

\subsection{Significance of the Study}

The studies on the impact of ICTs on hospitality sector of tourism industry are concentrated in USA and Europe and they are limited in the developing countries, especially in sub-Saharan Africa and Zambia (Sirirak et al., 2011). The literature on the effects of ICT on hospitality did not consider Zambia as a case study. Given the fact that Zambia is considered a tourism destination in the world and hospitality industry is significant sector for the Zambian economy, this study assumes importance. This study investigates the extent of use of ICTs in the hospitality sector of tourism to know the usage of technological advancement in economic development. Technological development and ICTs usage are inevitable for business development. The study investigates the impact of ICTs usage on marketing, room occupancy, profitability and access to finance in the tourism city of Livingstone in Zambia.

\section{Materials and Methods}

This study used multi-stage random sampling technique for selecting the sample. In the first stage Southern Province, out of 10 provinces in Zambia, was selected as the tourism industry in Zambia was concentrated in this province. In the second stage Livingstone - the tourism city of Zambia - was selected due to highest tourist activities. In the third stage different sources of 10 hotels, 10 motels, 20 guest houses and 10 lodges - thus a total of 50 sources of hospitality in tourism were selected. The study was based on the data collected for hospitality businesses from January to December 2017. The data were collected through questionnaire and interview methods on the use of mobile phone, land phone and internet. The information on sales, room occupancy, profitability and credit facilities was also collected.

Multiple regression model was fitted to know the impact of ICTs - mobile phone, land phone and internet - on room occupancy, profitability and credit facilities. The following econometric models were used to measure the relationship between the dependent and independent variables.

Model 1: $\mathrm{ROR}=\beta_{\mathrm{o}}+\beta_{1} \mathrm{mp}+\beta_{2} \mathrm{lp}+\beta_{3}$ is $+\mu$

Model 2: $\mathrm{BP}=\beta_{\mathrm{o}}+\beta_{1} \mathrm{mp}+\beta_{2} \mathrm{lp}+\beta_{3}$ is $+\mu$

Model 3: $\mathrm{CF}=\beta_{\mathrm{o}}+\beta_{1} \mathrm{mp}+\beta_{2} \mathrm{lp}+\beta_{3}$ is $+\mu$

Where, $\mathrm{ROR}=$ Room Occupancy Rate; $\mathrm{BP}=$ Business Profit and $\mathrm{CF}=$ Credit Facilities

MP = Mobile Phone; LP = Land Phone, IS = Internet Service and $\mu=$ Error term.

\section{Results and Discussion}

\subsection{Usage of ICTs}

The following table (1) shows the usage of different types of ICTs.

Table-1. Usage of different types of ICTs

\begin{tabular}{l|l|c}
\hline Type of ICT & Frequency & Percentage \\
\hline Mobile Phone & 35 & 70.0 \\
\hline Land Phone & 01 & 2.0 \\
\hline Internet & 14 & 28.0 \\
\hline Total & 50 & 100.0 \\
\hline
\end{tabular}

Table (1) shows that out of 50 respondents 70 percent were using mobile phones, 28 percent were using internet and only 2 percent were using land phone.

\subsection{Effect of ICTs Usage on Sales and Marketing Performance}

Table (2) shows the effect of ICT usage on Sales and Marketing Performance.

Table-2. Effect of ICT usage on Sales and Marketing Performance

\begin{tabular}{l|l|l}
\hline Sales/Marketing Performance & Frequency & Percent \\
\hline 1. Sales & & \\
\hline Up to K10,000 & 12 & 24.0 \\
\hline K10,001 - K40,000 & 29 & 58.0 \\
\hline K40,001 - K100,000 & 04 & 8.0 \\
\hline Above K100,000 & 05 & 10.0 \\
\hline Total & 50 & 100.0 \\
\hline 2.Marketing Performance & & \\
\hline Increased & 44 & 88.0 \\
\hline Decreased & 01 & 2.0 \\
\hline No Effect & 05 & 10.0 \\
Total & 50 & 100.0 \\
\hline Source: Primary data &
\end{tabular}

Source: Primary data 
Table ( 2 ) shows that the sales value of all the categories of business increased due to use of ICT The highest increase in sales was with respect to $\mathrm{K} 10,000-\mathrm{K} 40,000$ category (58 percent) and the lowest was with respect to K40,001 - K100,00 (8 percent).

With respect to marketing performance, 88 percent revealed that their performance increased, 2 percent revealed that it decreased and 10 percent had no effect due to use of ICTs. These results support the outcome of studies by Nwakanma et al. (2014); Mihalič et al. (2015); Seng (2015); and Mupfiga (2015).

\subsection{The Impact of ICTs on Room Occupancy Rate}

The model (1) below explains the impact of ICTs on room occupancy rate.

\begin{tabular}{|c|c|c|c|c|}
\hline \multicolumn{5}{|c|}{ el-1. Impact of ICTs on Room Occupancy Rate } \\
\hline Model & $\mathrm{R}$ & R Square & Adjusted R Square & Std. Error of the Estimate \\
\hline 1 & $.129^{\mathrm{a}}$ & .017 & -.057 & 1.03687 \\
\hline
\end{tabular}

ANOVA $^{\text {a }}$
\begin{tabular}{l|l|l|l|l|l|l}
\hline \multicolumn{1}{l}{ Model } & \multicolumn{1}{l}{ Sum of Squares } & df & \multicolumn{1}{l}{ Mean Square } & \multicolumn{1}{c}{ F } \\
\hline \multirow{2}{*}{1} & Regression & .723 & 3 & .241 & .224 & $.879^{\mathrm{b}}$ \\
\cline { 2 - 7 } & Residual & 43.004 & 40 & 1.075 & & \\
\cline { 2 - 7 } & Total & 43.727 & 43 & & & \\
\hline
\end{tabular}

a. Dependent Variable: room occupancy rate

b. Predictors: (Constant) internet, land phone and mobile phone

\section{Coefficientsa}

\begin{tabular}{|c|c|c|c|c|c|c|}
\hline \multicolumn{2}{|c|}{ Model } & \multicolumn{2}{|c|}{ Un-standardized Coefficients } & \multirow{2}{*}{$\begin{array}{l}\text { Standardized } \\
\text { Coefficients } \\
\text { Beta } \\
\end{array}$} & \multirow[t]{2}{*}{$\mathrm{t}$} & \multirow[t]{2}{*}{ Sig. } \\
\hline & & $\mathrm{B}$ & Std. Error & & & \\
\hline \multirow[t]{4}{*}{1} & (Constant) & .761 & 1.306 & & .582 & .564 \\
\hline & Mobile phones & .158 & .491 & .064 & .323 & .749 \\
\hline & Land phone & .946 & 1.156 & .141 & .818 & .418 \\
\hline & Internet service & .081 & .407 & .038 & .199 & .843 \\
\hline
\end{tabular}

\footnotetext{
a. Dependent Variable: room occupancy rate

Thus the regression equation for model 1 was:

$\mathrm{ROR}=0.761+0.158 \mathrm{mp}+0.946 \mathrm{lp}+0.081$ is

$\mathrm{t}=(0.582)(0.323)(0.818)(0.199)$

$\mathrm{R}^{2}=0.017$

$\mathrm{F}$ - statistic $=0.224$
}

The model (1) revealed that there was positive impact of ICTs on room occupancy rate. One percent increase in mobile phone usage increased the room occupancy rate by 15.8 percent, while holding land phone and internet constant. Whereas, one percent increase in land phone resulted in increase of room occupancy rate by 94.6 percent. But one percent increase in internet service resulted in increase of room occupancy rate by 8.1 percent only.

\subsection{The Impact of ICTs Usage on Profit of the Firm}

The Model (2) shows the impact of ICTs usage on profit of the firm

\begin{tabular}{|c|c|c|c|c|c|c|}
\hline \multicolumn{7}{|c|}{ Model-2. The Impact of ICTs Usage on Profit of the Firm } \\
\hline Model & $\mathrm{R}$ & R Square & \multicolumn{2}{|c|}{ Adjusted R Square } & \multicolumn{2}{|c|}{$\begin{array}{l}\text { Std. Error of the } \\
\text { Estimate }\end{array}$} \\
\hline 1 & $.219^{\mathrm{a}}$ & .048 & \multicolumn{2}{|c|}{-.023} & \multicolumn{2}{|c|}{1.80556} \\
\hline \multicolumn{7}{|c|}{ a. Predictors: (Constant), internet, land phone and mobile phone } \\
\hline \multicolumn{7}{|c|}{ ANOVA $^{\mathrm{a}}$} \\
\hline \multicolumn{2}{|l|}{ Model } & Sum of Squares & $\mathrm{df}$ & Mean Square & $\mathrm{F}$ & Sig. \\
\hline \multirow[t]{3}{*}{1} & Regression & 6.576 & 3 & 2.192 & .672 & $.574^{b}$ \\
\hline & Residual & 130.402 & 40 & 3.260 & & \\
\hline & Total & 136.977 & 43 & & & \\
\hline
\end{tabular}


Coefficients $^{\mathrm{a}}$

\begin{tabular}{|c|c|c|c|c|c|c|}
\hline \multicolumn{2}{|c|}{ Model } & \multicolumn{2}{|c|}{ Un-standardized Coefficients } & \multirow{2}{*}{$\begin{array}{l}\text { Standardized } \\
\text { Coefficients } \\
\text { Beta }\end{array}$} & \multirow[t]{2}{*}{$\mathbf{t}$} & \multirow[t]{2}{*}{ Sig. } \\
\hline & & B & Std. Error & & & \\
\hline \multirow[t]{4}{*}{1} & (Constant) & 3.359 & 2.274 & & 1.477 & .148 \\
\hline & Mobile phones & .834 & .854 & .191 & .976 & .335 \\
\hline & Land phones & .081 & 2.013 & .007 & .040 & .968 \\
\hline & Internet & -.193 & .710 & -.051 & -.272 & .787 \\
\hline
\end{tabular}

a. Dependent Variable: profit per month

The model (2) shows that the impact of mobile phone and land phone on profitability of the firm was positive but it was negative with respect to internet usage. When the mobile phone usage increased by one percent the profitability of the firm increased by 83.4 percent. Whereas, one percent increase in land phone resulted in increase of only 8.1 percent in profitability. On the other hand, one percent increase in internet usage decreased the profit of the firm by 19.3 percent. These results did not concur with the study by Ham et al. (2005) which concluded that the information technology had no influence on hotels' performance. On the other hand, one percent increase in internet usage resulted in decrease of profit by 19.3 percent. These results did not support the outcome of the studies by Jeong and Lambert (2001), Schegg and Scaglione (2013) and Litvin et al. (2008).

\subsection{The impact of ICTs usage on Credit Facilities}

The Model (3) shows the impact of ICTs usage on credit facilities

\begin{tabular}{|c|c|c|c|c|c|}
\hline \multicolumn{6}{|c|}{. The Impact of ICTs Usage on Credit Facilities } \\
\hline \multirow[t]{2}{*}{ Model } & $\mathrm{R}$ & \multirow[t]{2}{*}{ R Square } & \multicolumn{2}{|r|}{ Adjusted R Square } & $\begin{array}{l}\text { Std. Error of the } \\
\text { Estimate }\end{array}$ \\
\hline & .384 & & & .083 & .47159 \\
\hline \multicolumn{6}{|c|}{ a. Predictors: (Constant), internet, land phone and mobile phone } \\
\hline \multicolumn{6}{|c|}{ ANOVA $^{\text {a }}$} \\
\hline \multicolumn{2}{|l|}{ Model } & Sum of Squares & df & Mean Square & Sig. \\
\hline \multirow[t]{3}{*}{1} & Regression & 1.536 & 3 & .512 & 2.302 \\
\hline & Residual & 8.896 & 40 & .222 & \\
\hline & Total & 10.432 & 43 & & \\
\hline
\end{tabular}

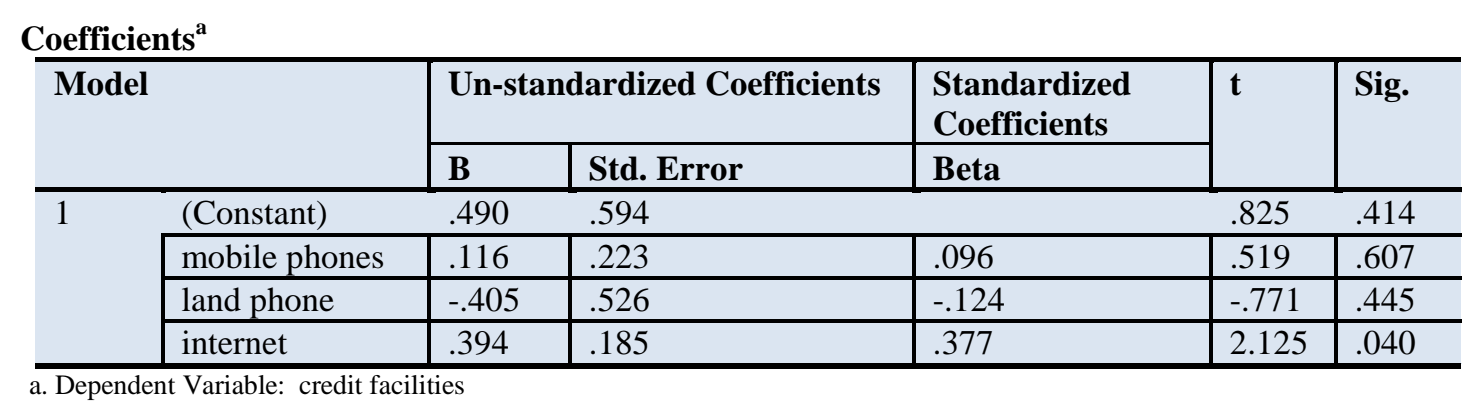

The Model (3) shows that the impact of ICTs on credit facilities was positive. One percent increase in mobile phones usage increased the credit facilities by 11.6 percent. Whereas, one percent increase in the use of land phone decreased by 40.5 percent and internet increased the credit facilities by 39.4 percent respectively.

\section{Conclusion}

Since the use of mobile phone, land phone and internet services resulted in increase of sales and marketing performance of the firm, room occupancy rate and the credit facilities, the firms in the hospitality sector of the tourism should be encouraged to use them. The use of internet had positive impact on sales and marketing performance of the firm, room occupancy and credit facilities but it had negative impact on the profitability of the firm because of higher costs of installation of internet service. Hence, there is need for the firms to work together as a pool to reduce costs, such as the use of trivago.co.zm; booking.co.zm; hotels.com; agoda.com; expedia.com; etc.,

\section{References}

Ali, S. (2015). Employment and income effects of tourism activities in the tourism city of livingstone in Zambia. International Journal of Economics, Finance and Manage-ment Sciences, 3(5): 577-82.

Ali, S. and Christopher, N. (2017). The impact of exchange rate volatility on hospitality industry- a study in lusaka province of Zambia. International Journal of Economics And Financial Research, 3(11): 282-88. 
Ansah, A. K., Blankson, V. S. and Kontoh, M. (2012). The use of information and communication technologies (icts) in front office operations of chain hotels in Ghana. International Journal of Advanced Computer Science And Applications, 3(3): 72-77.

Aziz, A. A., Bakhtiar, M., Syaquif, M., Kamaruddin, Y. and Ahmad, N. (2012). Information and communication technology application's usage in hotel industry. Journal of Tourism, Hospitality, and Culinary Arts, 4(2): $34-48$.

Buhalis, D. (2003). E-tourism, Information technology for strategic tourism management. Pearson, Financial Times/Prentice Hall: London, UK.

Chevers, D. A. (2015). Evaluating the impact of ict usage on the performance of jamaican hotels, A conceptual perspective. Journal of Tourism and Hospitality Management, 3(1-2): 22-31.

Ham, S., Kim, W. G. and Jeong, S. (2005). Effect of information technology on performance $\backslash$ in upscale hotels. International Journal of Hospitality Management, 24(2): 281-94.

Jeong, M. and Lambert, C. U. (2001). Adaptation of an information quality framework to measure customers behavioral intentions to use lodging web sites. International Journal Of Hospitality Management, 20(2): 129-46.

Karadag, E. and Dumanoglu, S. (2009). The productivity and competency of information technology in upscale hotels. International Journal of Contemporary Hospitality Management, 21(4): 479-90.

Kim, T. G., Lee, J. H. and Law, R. (2008). An empirical examination of the acceptance behaviour of hotel front office systems, An extended technology acceptance model. Tourism Management, 29(3): 500-13.

Law, R., Leung, R. and Buhalis, D. (2009). Information technology applications in hospitality and tourism, A review of publications from 2005 to 2007. Journal of Travel \& Tourism Marketing, 26(5-6): 599-623.

Lee, B. and Shafer, C. S. (2003). Operationalizing sustainability in regional tourism planning, An application of the limits of acceptable change framework. Tourism Management, 23(1): 1-15.

Litvin, S. W., Goldsmith, R. E. and Pan, B. (2008). Electronic word-of-mouth in hospitalityand tourism management. Tourism Management, 29(3): 458-68.

Mc. Manus, L. (2013). Customer accounting and marketing performance measures in the hotel industry, Evidence from australia. International Journal Of Hospitality Management, 33(N/A): 140-52.

Mihalič, T., Praničević, D. G. and Arnerić, J. (2015). The changing role of ict competitiveness: The case of the slovenian hotel sector. Economic Research- Ekonomska Istraživanja, 28(1): 367-83.

Mupfiga, S. P. (2015). Adoption of ict in the tourism and hospitality sector in zimbabwe", midlands state university. The International Journal Of Engineering And Science, 4(12): 2319 - 1805. Available: www.theijes.com,

Murphy, H. C. (2013). The property management system, The view from the front desk on training and performance. In: Z. Xiang and i. Tussyadiah eds, information and communication technologies in tourism. Springer: London. 777-83.

Murphy, J., Schegg, R. and Olaru, D. (2016). Investigating the evolution of hotel internet adoption. Information Technology \& Tourism, 8(3-4): 161-77.

Ngatia, T. J., Mwenda, L. and Wachira, A. W. (2014). Determinants of information communication technology in kenya's hotel industry: A case of mt kenya tourism circuit. Kenya Journal of Technical And Vocational Education \& Training, 2(1): 134-45.

Nwakanma, I., Ubani, E., Asiegbu, B. and Nwokonkwo, O. (2014). Factors affecting the adoption of ict in the hospitality industry in imo state. International Journal Of Computer Science Issues, 11(4): 170-81.

Paço, C. M. L. and Pérez, J. M. C. (2015). Assessing the impact of information and communication technologies on the portuguese hotel sector, An exploratory analysis with data envelopment analysis. Tourism \& Management Studies, 11(1): 35-43.

Paryani, K., Masoudi, A. and Cudney, E. A. (2010). QFD application in the hospitality industry: A hotel case study. Quality Management Journal, 17(1): 7-28.

Piccoli, G. (2008). Information technology in hotel management, A framework for evaluating the sustainability of it-dependent competitive advantage. Cornell Hospitality Quarterly, 49(3): 282-96.

Porter, M. E. (1998). Competitive advantage, Creating and sustaining superior performance. The Free Press: New York.

Prayukvong, W., Sophon, J., Hongpukdee, S. and Charupas, T. (2007). Customers'satisfaction with hotel guestrooms: A case study in Ubon Rachathani Province,Thailand. Asia Pacific Journal of Tourism Research, 12(2): 119-26.

Reino, S. P., Lamsfus, C., Salas, H., Torices, O. and Alzua-Sorzabal, A. (2013). Listening to ceos, A new perspective to study technology adoption in hotels. In, Z. Xiang and richard, 1(2013). The role of ict in the hospitality industry. International Journal Of Scientific Research, 2(9): 49-51.

Schegg, R. and Scaglione, M. (2013). Substitution effects across hotel distribution channels. In, Z. Xiang and i. Tussyadiah eds. Information and communication technologies in tourism. Springer: London. 801-12.

Seng, B. (2015). Ict for sustainable development of the tourism industry in cambodia. In, Q. Zu, b. Hu, n. Gu and s. Seng eds, Human centered computing. Springer: New York. 1-14.

Sirirak, S., Islam, N. and Khang, D. (2011). Does ict adoption enhance hotel performance? Journal of Hospitality and Tourism Technology, 2(1): 34-49.

UNWTO (2014). Measuring employment in the tourism industries, Guide with best practice. Madrid: Spain. 16-29.

UNWTO (2015). Unwto. Madrid: Spain.

UNWTO (2018). Unwto tourism highlights, 2018 edition, world tourism organization. 
Wang, Y. (2008). Web-based destination marketing systems, Assessing the critical factors for management and implementation. International Journal Of Tourism Research, 10(1): 55-70.

World Economic Forum (2013). The travel and tourism competitiveness report, Travel and tourism as a driver of employment growth. WEF: 63-69.

Xiang, Z. and Richard, L. (2013). The role of ict in the Hospitality industry. International Journal Of Scientific Research, 2(9): 49-51. 